Research Article

\title{
ANTIFEEDANT ACTIVITY OF FOUR PLANT ESSENTIAL OILS AGAINST MAJOR STORED PRODUCT INSECT PESTS
}

\author{
Jyotika Brari* and Varun Kumar
}

Department of Zoology, Abhilashi University, Mandi, India

Article History: Received $21^{\text {st }}$ May, 2019; Accepted 05 ${ }^{\text {th }}$ June, 2019; Published $15^{\text {th }}$ June, 2019

\begin{abstract}
Experiments were carried out in the laboratory to determine antifeedant activity of four plant essential oils of Rabdosia rugosa (Wall. ex Benth), Zanthoxylum armatum (DC.), Artemisia maritima (L.) and Colebrookea oppositifolia (Sm.) against four stored product insect pests viz. Tribolium castaneum (Herbst.), Sitophilus oryzae (L.), Stegobium paniceum (L.) and Plodia interpunctella (Hubner). Feeding deterrence indices (FDI) showed that the plant essential oils had antifeedant action against the four insect pests at different concentrations. R. rugosa and Z. armatum oil at a high concentration of $300 \mu 1 / \mathrm{g}$ resulted in $5.22 \pm$ 0.21 and $6.42 \pm 0.32 \%$ grain damage as compared to $70.32 \pm 0.28 \%$ damage under control and FDI of $86.17 \pm 0.25$ and 85.71 $\pm 0.27 \%$ was recorded for T. castaneum followed by $S$. oryzae with a FDI of $70.58 \pm 0.21$ and $67.68 \pm 0.19 \%$ and grain damage of $15.42 \pm 0.12$ and $16.31 \pm 0.21 \%$ as compared to $85.36 \pm 0.09 \%$ grain damage in control for similar concentrations of above oils. A. maritima oil at $100 \mu \mathrm{l} / \mathrm{g}$ showed $76.31 \pm 0.16 \%$ FDI followed by C. oppositifolia oil obtaining $75.11 \pm 0.35 \%$ feeding deterrence against $T$. castaneum whereas $65.99 \pm 0.32 \%$ and $65.46 \pm 0.14 \%$ FDI was obtained for similar concentrations of these oils against $S$. oryzae. FDI of $62.82 \pm 0.32$ and $60.03 \pm 0.26 \%$ was observed for $R$. rugosa and Z. armatum oil at $300 \mu 1 / g$ against $S$. paniceum followed by $64.97 \pm 0.14$ and $53.35 \pm 0.18 \%$ against $P$. interpunctella for similar concentration of oils. The present study indicated that $R$. rugosa and $Z$. armatum were highly effective followed by A. maritima and C. oppositifolia against all the insect pest.
\end{abstract}

Keywords: Essential oils; Antifeedant activity; Deterrence, Grain damage; Insect pests

\section{INTRODUCTION}

Stored grain insect pests can cause reductions in weight, quality, commercial value and seed viability. Seventyfive percent of these insects are Coleopterans and the most damaging species of storage insects are in the genera Sitophilus and Tribolium (Marsans, 1987; Khan and Selman, 1988; Pinto et al., 1997). S. paniceum is the most extensively distributed insect pest causing serious damages to stored products (Can et al., 2004; Guilin and Wangxi, 1996). Indian meal moth, $P$. interpunctella (Lepidoptera: Pyralidae), is a serious pest of stored products like grains, seeds, flour and other milled products and has a universal distribution (Nansen et al., 2004). The use of chemical agents to prevent or control insect infestations has been the main method of grain protection, since it is the simplest and most cost-effective means of dealing with stored product pests (Hidalgo et al., 1998). Although effective, their repeated use for decades has disrupted biological control by natural enemies and led to resurgence of stored-product insect pests (Brower et al., 1995), sometimes resulted in the development of resistance (Champ and Dyte, 1977; Subramanyam and Hagstrum, 1995; White and Leesch, 1995), had undesirable effects on nontarget organisms, and fostered environmental and human health concerns (Brown, 1978; Hayes and Laws, 1991; White and Leesch, 1995). Much effort has, therefore, been focused on plant-derived materials as potential sources of commercial insect-control agents (Hill and Schoonhoven, 1981; Coats et al., 1991; Konstantopoulou et al., 1992). The biggest impetus for the growth of biopesticides comes from the growing awareness by farmers of the value of integrated pest management as a more environmentally sound, economical, safer and a selective approach to crop protection (Menn, 1996). A large number of plant-derived substances possess various physiological and behavioral activities against storedproduct insects. These include toxic, repellent and antifeedant effects (Amason et al., 1989; Grainge and Ahmed, 1988; Jacobson, 1990). Pesticides based on plant essential oils or their constituents have demonstrated efficacy against a range of stored product pests, domestic pests, blood feeding pests and certain soft bodied agricultural pests, as well as against some plant pathogenic fungi responsible for pre and postharvest diseases. They may be applied as fumigants, granular formulations or direct sprays with a range of effects from lethal toxicity to repellence and oviposition deterrence in insects. These features indicate that pesticides based on plant essential oils could be used in a variety of ways to control a large number of pests. Essential oils, which are volatile oils from plants and their constituents, have been shown to be a potent source of botanical pesticides (Singh and Upadhyay, 
1993). The present study was carried out in the laboratory to determine antifeedant activity of four plant essential oils of Rabdosia rugosa (Wall. ex Benth), Zanthoxylum armatum (DC.), Artemisia maritima (L.) and Colebrookea oppositifolia (Sm.) against four stored product insect pests viz. Tribolium castaneum (Herbst.), Sitophilus oryzae (L.), Stegobium paniceum (L.) adults and larvae of Plodia interpunctella (Hubner).

\section{MATERIALS AND METHODS}

\section{Extraction of essential oils}

Essential oils were extracted from leaves of $R$. rugosa, $Z$. armatum, A. maritima and $C$. oppositifolia collected from the local areas of Shimla district of Himachal Pradesh, India. The leaves were dried in shade at room temperature $30 \pm$ $5 \square)$ and grounded by domestic mixer. The dried powdered material was hydro-distilled in Clevenger apparatus. Conditions of extraction were: $50 \mathrm{~g}$ of air-dried sample in 1:10 plant material/water volume ratio for $4 \mathrm{hrs}$ distillation. Oil yield $(2.9 \% \mathrm{w} / \mathrm{w})$ was calculated on a dry weight basis.

\section{Test insects}

Laboratory cultures of $P$. interpunctella, T. castaneum, $S$. oryzae and S. paniceum were maintained at $28 \pm 2{ }^{\circ} \mathrm{C}$

and $68 \pm 2 \%$ relative humidity. Adult insects of $T$. castaneum, $S$. oryzae and $S$. paniceum were reared on wholemeal wheat flour plus brewer's yeast (19:1) and larvae of $P$. interpunctella was reared on a diet of $80 \%$ ground rice, $10 \%$ glycerin, $5 \%$ yeast in plastic containers $(30 \mathrm{~cm}$ length $\times 20 \mathrm{~cm}$ width $\times 8$ $\mathrm{cm}$ height). Mouth of the containers was covered with fine mesh cloth for ventilation as well as to prevent escape of the insects.

\section{Antifeedant activity of essential oils}

The bioassay experiment was conducted for evaluating essential oils as potential seed protectants against $T$. castaneum, S. oryzae, S. paniceum (5-10 day old) adults and larvae (16 day old) of $P$. interpunctella. To determine antifeedant activity of essential oils a no-choice test was carried out as described by Huang et al. (2002) and Gomah (2011) with some modifications. $1 \mathrm{ml}$ of prepared concentrations of 100 and $300 \mu$ of essential oils dissolved in methanol and $1 \mathrm{ml}$ solvent alone as control were applied on to a $5 \mathrm{~g}$ grinded mixture of pulses and rice kernels. The treated mixture of food media were placed in Petri dishes after evaporating the solvent. 10 adults of $T$. castaneum, $S$. oryzae, $S$. paniceum and larvae of $P$. interpunctella were transferred to each pre-weighed food media in Petri dishes. After feeding for $72 \mathrm{hrs}$ under laboratory conditions food media was re-weighed and mortality of insects was recorded. Nutritional indices and weight loss were calculated as previously described by Mahdi (2008) and Huang et al. (2002).

Weight loss $(\% \mathrm{WL})=(\mathrm{IW}-\mathrm{FW}) \times 100 / \mathrm{IW}$, where the IW is the initial weight and FW is the final weight.
Feeding Deterrence Index was calculated by (Isman et al. 1990; Huang Ho et al. 2003) using the formula,

FDI $(\%)=(\mathrm{C}-\mathrm{T}) /(\mathrm{C}+\mathrm{T}) \times 100$, where $\mathrm{C}$ is weight loss of control rice kernels and $\mathrm{T}$ is weight loss of treated rice kernels.

\section{Statistical analysis}

All the data concerning mortality were corrected by using Abbott's formula (Abbott, 1925). Tests for antifeedant activity were performed in triplicate and data presented are mean $\pm \mathrm{SE}$. The mean values were compared by one-way ANOVA and Tukey's multiple comparison tests using software SPSS, version 11.5.

\section{RESULTS}

\section{Antifeedant activity of essential oils against $T$. castaneum}

$5.22 \pm 0.21$ and $6.42 \pm 0.32 \%$ grain damage was observed for $R$. rugosa and $Z$. armatum oil at a high concentration of 300 $\mu \mathrm{l} / \mathrm{g}$ as compared to $70.32 \pm 0.28 \%$ damage under control and FDI of $86.17 \pm 0.25$ and $85.71 \pm 0.27 \%$ was recorded for T. castaneum. A. maritima oil at $100 \mu \mathrm{l} / \mathrm{g}$ showed $76.31 \pm$ $0.16 \%$ FDI with $9.25 \pm 0.26 \%$ grain damage followed by $C$. oppositifolia oil obtaining $75.11 \pm 0.35 \%$ feeding deterrence with $9.48 \pm 0.18 \%$ grain damage (Table 1 ).

\section{Antifeedant activity of essential oils against $S$. oryzae}

R. rugosa and Z. armatum oil at $300 \mu \mathrm{l} / \mathrm{g}$ showed high FDI of $70.58 \pm 0.21$ and $67.68 \pm 0.19 \%$ with $15.42 \pm 0.12$ and 16.31 $\pm 0.21 \%$ grain damage as compared to $85.36 \pm 0.09 \%$ grain damage in control. $65.99 \pm 0.32$ and $58.94 \pm 0.09 \%$ FDI was obtained at 100 and $300 \mu \mathrm{l} / \mathrm{g}$ of $A$. maritima oil while $65.46 \pm$ 0.14 and $56.99 \pm 0.26 \%$ feeding deterrence was observed by C. oppositifolia oil against $S$. oryzae (Table 2).

\section{Antifeedant activity of essential oils against S. paniceum}

FDI of $62.82 \pm 0.32$ and $60.03 \pm 0.26 \%$ was observed for $R$. rugosa and $Z$. armatum oil at $300 \mu \mathrm{l} / \mathrm{g}$ followed by $57.71 \pm$ 0.09 and $54.80 \pm 0.13 \%$ at $100 \mu \mathrm{l} / \mathrm{g} .19 .48 \pm 0.15$ and $20.05 \pm$ $0.34 \%$ grain damage was recorded at $300 \mu \mathrm{l} / \mathrm{g}$ of $A$. maritima and $C$. oppositifolia oil with $54.70 \pm 0.28$ and $50.09 \pm 0.11 \%$ FDI against $S$. paniceum and $79.32 \pm 0.30 \%$ grain damage in control (Table 3).

\section{Antifeedant activity of essential oils against $P$. interpunctella}

R. rugosa oil at lowest concentration of $100 \mu \mathrm{l} / \mathrm{g}$ showed $59.30 \pm 0.18 \%$ feeding deterrency with $21.32 \pm 0.13 \%$ grain damage followed by $Z$. armatum oil producing $45.93 \pm 0.24$ feeding deterrency with $23.16 \pm 0.17 \%$ grain damage as compared to $78.26 \pm 0.34 \%$ grain damage in control against $P$. interpunctella. Similarly A. maritima and C. oppositifolia oil obtained $41.71 \pm 0.09$ and $36.70 \pm 0.30 \%$ FDI at $100 \mu \mathrm{l} / \mathrm{g}$ and $51.85 \pm 0.28$ and $46.51 \pm 0.17 \%$ FDI was recorded at a concentration of $300 \mu \mathrm{l} / \mathrm{g}$ respectively (Table 4). 
Table 1: Antifeedant activity of essential oils against $T$. castaneum (Values are mean $\pm \mathrm{SE}$ ).

\begin{tabular}{|c|c|c|c|c|}
\hline Essential oils & Doses $\mu \mathrm{l} / \mathrm{g}$ & Grain damage (\%) & Weight loss (\%) & FDI (\%) \\
\hline \multirow{2}{*}{ R. rugosa } & 100 & $7.32 \pm 0.16^{\mathrm{a}}$ & $5.42 \pm 0.32^{\mathrm{a}}$ & $78.60 \pm 0.09^{b}$ \\
\hline & 300 & $5.22 \pm 0.21^{b}$ & $3.36 \pm 0.26^{\mathrm{b}}$ & $86.17 \pm 0.25^{\mathrm{c}}$ \\
\hline \multirow{2}{*}{ Z. armatum } & 100 & $8.54 \pm 0.11^{\mathrm{a}}$ & $5.56 \pm 0.17^{\mathrm{a}}$ & $78.11 \pm 0.13^{b}$ \\
\hline & 300 & $6.42 \pm 0.32^{b}$ & $3.48 \pm 0.21^{\mathrm{b}}$ & $85.71 \pm 0.27^{\mathrm{c}}$ \\
\hline \multirow{2}{*}{ A. maritima } & 100 & $9.25 \pm 0.26^{c}$ & $6.08 \pm 0.35^{\mathrm{c}}$ & $76.31 \pm 0.16^{\mathrm{b}}$ \\
\hline & 300 & $6.52 \pm 0.09^{b}$ & $4.24 \pm 0.09^{d}$ & $82.86 \pm 0.08^{a}$ \\
\hline \multirow{2}{*}{ C. oppositifolia } & 100 & $9.48 \pm 0.18^{\mathrm{c}}$ & $6.43 \pm 0.16^{\mathrm{c}}$ & $75.11 \pm 0.35^{b}$ \\
\hline & 300 & $7.05 \pm 0.32^{\mathrm{a}}$ & $4.46 \pm 0.23^{\mathrm{d}}$ & $82.05 \pm 0.09^{a}$ \\
\hline Control & _ & $70.32 \pm 0.28^{\mathrm{ab}}$ & $45.25 \pm 0.32^{\mathrm{ab}}$ & \\
\hline
\end{tabular}

$\%$ values are mean $(n=3) \pm$ SE. The means within a column followed by same letter are not significantly different from each other according to ANOVA and Tukey's comparison tests.

Table 2: Antifeedant activity of essential oils against S.oryzae (Values are mean $\pm \mathrm{SE}$ ).

\begin{tabular}{|c|c|c|c|c|}
\hline Essential oils & Doses $\boldsymbol{\mu l} \mathbf{g}$ & Grain damage (\%) & Weight loss (\%) & FDI (\%) \\
\hline \multirow{2}{*}{ R. rugosa } & 100 & $19.42 \pm 0.33^{\mathrm{a}}$ & $12.32 \pm 0.22^{\mathrm{b}}$ & $65.60 \pm 0.19^{\mathrm{a}}$ \\
\cline { 2 - 5 } & 300 & $15.42 \pm 0.12^{\mathrm{b}}$ & $10.23 \pm 0.15^{\mathrm{b}}$ & $70.58 \pm 0.21^{\mathrm{b}}$ \\
\hline \multirow{2}{*}{ Z. armatum } & 100 & $20.25 \pm 0.27^{\mathrm{a}}$ & $13.16 \pm 0.33^{\mathrm{b}}$ & $63.68 \pm 0.17^{\mathrm{a}}$ \\
\hline \multirow{2}{*}{ A. maritima } & 300 & $16.31 \pm 0.21^{\mathrm{b}}$ & $11.43 \pm 0.11^{\mathrm{a}}$ & $67.68 \pm 0.19^{\mathrm{c}}$ \\
\cline { 2 - 5 } & 100 & $22.42 \pm 0.13^{\mathrm{c}}$ & $15.32 \pm 0.09^{\mathrm{c}}$ & $58.94 \pm 0.09^{\mathrm{d}}$ \\
\hline \multirow{2}{*}{ C. oppositifolia } & 300 & $18.45 \pm 0.22^{\mathrm{b}}$ & $12.15 \pm 0.26^{\mathrm{a}}$ & $65.99 \pm 0.32^{\mathrm{a}}$ \\
\hline Control & 100 & $19.18 \pm 0.36^{\mathrm{a}}$ & $16.25 \pm 0.17^{\mathrm{c}}$ & $56.99 \pm 0.26^{\mathrm{d}}$ \\
\hline \multirow{2}{*}{. } & 300 & $85.36 \pm 0.09^{\mathrm{ab}}$ & $59.32 \pm 0.26^{\mathrm{ab}}$ & $65.46 \pm 0.14^{\mathrm{a}}$ \\
\hline
\end{tabular}

$\%$ values are mean $(n=3) \pm$ SE. The means within a column followed by same letter are not significantly different from each other according to ANOVA and Tukey's comparison tests.

Table 3: Antifeedant activity of essential oils against $S$. paniceum (Values are mean $\pm \mathrm{SE}$ ).

\begin{tabular}{|c|c|c|c|c|}
\hline \multirow{2}{*}{ Essential oils } & Doses $\boldsymbol{\mu l} / \mathbf{g}$ & Grain damage (\%) & Weight loss (\%) & FDI (\%) \\
\hline \multirow{2}{*}{ R. rugosa } & 100 & $18.32 \pm 0.23^{\mathrm{a}}$ & $13.15 \pm 0.17^{\mathrm{b}}$ & $57.71 \pm 0.09^{\mathrm{a}}$ \\
\cline { 2 - 5 } & 300 & $15.00 \pm 0.09^{\mathrm{b}}$ & $11.20 \pm 0.32^{\mathrm{b}}$ & $62.82 \pm 0.32^{\mathrm{b}}$ \\
\hline \multirow{2}{*}{ Z. armatum } & 100 & $20.05 \pm 0.23^{\mathrm{a}}$ & $14.32 \pm 0.19^{\mathrm{b}}$ & $54.80 \pm 0.13^{\mathrm{c}}$ \\
\cline { 2 - 5 } & 300 & $17.36 \pm 0.17^{\mathrm{a}}$ & $12.25 \pm 0.09^{\mathrm{a}}$ & $60.03 \pm 0.26^{\mathrm{d}}$ \\
\hline \multirow{2}{*}{ A. maritima } & 100 & $22.43 \pm 0.32^{\mathrm{c}}$ & $16.41 \pm 0.32^{\mathrm{b}}$ & $49.86 \pm 0.33^{\mathrm{bc}}$ \\
\hline \multirow{2}{*}{ C. oppositifolia } & 300 & $19.48 \pm 0.15^{\mathrm{a}}$ & $14.36 \pm 0.14^{\mathrm{b}}$ & $54.70 \pm 0.28^{\mathrm{c}}$ \\
\hline Control & 100 & $23.26 \pm 0.15^{\mathrm{c}}$ & $18.10 \pm 0.12^{\mathrm{b}}$ & $46.09 \pm 0.15^{\mathrm{bc}}$ \\
\hline
\end{tabular}

$\%$ values are mean $(n=3) \pm$ SE. The means within a column followed by same letter are not significantly different from each other according to ANOVA and Tukey's comparison tests.

Table 4: Antifeedant activity of essential oils against $P$. interpunctella (Values are mean $\pm \mathrm{SE}$ ).

\begin{tabular}{|c|c|c|c|c|}
\hline Essential oils & Doses $\boldsymbol{\mu l} / \mathbf{g}$ & Grain damage (\%) & Weight loss (\%) & FDI (\%) \\
\hline \multirow{2}{*}{ R. rugosa } & 100 & $21.32 \pm 0.13^{\mathrm{a}}$ & $11.32 \pm 0.11^{\mathrm{b}}$ & $59.30 \pm 0.18^{\mathrm{a}}$ \\
\cline { 2 - 5 } & 300 & $18.42 \pm 0.09^{\mathrm{b}}$ & $9.41 \pm 0.21^{\mathrm{a}}$ & $64.97 \pm 0.14^{\mathrm{a}}$ \\
\hline \multirow{2}{*}{ Z. armatum } & 100 & $23.16 \pm 0.17^{\mathrm{c}}$ & $16.41 \pm 0.17^{\mathrm{c}}$ & $45.95 \pm 0.24^{\mathrm{c}}$ \\
\hline \multirow{2}{*}{ A. maritima } & 300 & $20.42 \pm 0.34^{\mathrm{a}}$ & $13.48 \pm 0.32^{\mathrm{b}}$ & $53.35 \pm 0.18^{\mathrm{d}}$ \\
\cline { 2 - 5 } & 100 & $24.31 \pm 0.21^{\mathrm{c}}$ & $18.23 \pm 0.24^{\mathrm{c}}$ & $41.71 \pm 0.09^{\mathrm{c}}$ \\
\hline \multirow{2}{*}{ C. oppositifolia } & 300 & $21.27 \pm 0.35^{\mathrm{a}}$ & $14.05 \pm 0.16^{\mathrm{b}}$ & $51.85 \pm 0.28^{\mathrm{d}}$ \\
\hline Control & 100 & $27.16 \pm 0.14^{\mathrm{d}}$ & $20.52 \pm 0.21^{\mathrm{c}}$ & $36.70 \pm 0.30^{\mathrm{bc}}$ \\
\hline
\end{tabular}

$\%$ values are mean $(n=3) \pm$ SE. The means within a column followed by same letter are not significantly different from each other according to ANOVA and Tukey's comparison tests. 


\section{DISCUSSION AND CONCLUSION}

Feeding deterrence indices (FDI) showed that the tested plant essential oils had antifeedant action against the four insect pests at different concentrations. In a related study Kumar et al. (2007) and Varma and Dubey (2001) investigated that essential oil of Cymbopogon martinii, Caesulia axillaris and Mentha arvensis protected stored gram and wheat from Callosobruchus chinensis, S. oryzae and T. castaneum for first 12 months of storage. R. rugosa and Z. armatum oil at a high concentration of $300 \mu \mathrm{l} / \mathrm{g}$ showed $86.17 \pm 0.25$ and 85.71 $\pm 0.27 \%$ FDI for $T$. castaneum followed by $S$. oryzae $(70.58 \pm$ 0.21 and $67.68 \pm 0.19), S$. paniceum $(62.82 \pm 0.32$ and 60.03 $\pm 0.26)$ and $P$. interpunctella (64.97 \pm 0.14 and $53.35 \pm 0.18)$. Kumar et al. (2008) recorded 91.51, 97.26, 98.02 and 6.18\% feeding deterrent index of essential oil of Aegle marmelos for $C$. chinensis, Rhizopertha dominica, S. oryzae and $T$. castaneum with $100 \%$ grain damage in $T$. castaneum while $7.0,3.67$ and $1.67 \%$ grain damage was found in $C$. chinensis. $R$. dominica and $S$. oryzae infested grains respectively. $A$. maritima and C. oppositifolia oil at $300 \mu \mathrm{l} / \mathrm{g}$ obtained $82.86 \pm$ 0.08 and $82.05 \pm 0.09 \%$ FDI for T. castaneum whereas 65.99 \pm 0.32 and $65.46 \pm 0.14 \%$ against $S$. oryzae. The result of present investigation are also similar to the observations of Shukla et al. (2011) who reported significant deterrent effects of essential oils of Lippia alba and Callistemon lanceolatus and their constituents on the feeding behaviour of $C$. chinensis and all the treatments showed significantly better results than the controls. Khani et al. (2013) investigated that petroleum ether extract of Piper nigrum and Jatropha curcas showed a positive dose dependent antifeedant activity and reduced consumption of rice kernels treated with both plant extract by Corcyra cephalonica larvae. R. rugosa oil at a concentration of $100 \mu \mathrm{l} / \mathrm{g}$ showed $59.30 \pm 0.18 \%$ feeding deterrency with $21.32 \pm 0.13 \%$ grain damage followed by $Z$. armatum oil producing $45.93 \pm 0.24$ feeding deterrency with $23.16 \pm 0.17 \%$ grain damage as compared to $78.26 \pm 0.34 \%$ grain damage in control against $P$. interpunctella. Least antifeedent activity was observed for $C$. oppositifolia oil towards all insect species. Essential oils inhibits locomotion which affect mating activities and sexual communication as well as deterring females from laying eggs, as well as complete suppression of the developmental stages of insects which have been reported by a number of authors (Ivbijaro and Agbaje, 1986; Ofuya, 1992; Okonkwo and Okoye, 1996; Adedire 2002). Compounds with feeding deterrents are generally toxic to insects or cause physiological disturbances of development or oviposition (Nawrot and Harmantha, 1994).

\section{REFERENCES}

1. Adedire, C.O. (2002). Use of nutmeg, Myristica fragrans (Houtt) powder and oil for the control of cowpea storage bruchid. Callosobruchus maculatus. Journal of Plant Diseases and Protection., 109: 193-199.

2. Amason. J. T., Philogene, B. J. R. and Morand, F. (1989). Insecticides of Plant Origin. American Chemical Society. Washington, DC.
3. Brower, J. H., Smith, L., Vail, P. V., Flinn, P. W. (1995). Biological control. In: Subramanyam, B., Hagstrum, D.W. (Eds.), Integrated Management of Insects in Stored Products. Marcel Dekker, New York, pp. 223-286.

4. Brown, A. W. A. (1978). Ecology of Pesticides. Wiley, New York, 525pp.

5. Can, L., Zizhong, L., Youlian, Y. (2004). Analysis of the structure of insect community on the stored Chinese medicinal materials in Guiyang. Journal of mountain agriculture and biology., 23: 41-45.

6. Champ, B. R., Dyte, C. E. (1977). FAO global survey of pesticide susceptibility of stored grain pests. FAO Plant Protection Bulletin., 25: 49-67.

7. Coats, J. R., Karr, L. L., Drewes, C. D. (1991). Toxicity and neurotoxic effects of monoterpenoids in insects and earthworms. In: Hedin, P.A. (Ed.), Naturally Occurring Pest Bioregulators. ACS Symposium Series No. 449. American Chemical Society, Washington, DC., 305-316.

8. Gomah, E. N., (2011). Toxic and antifeedant activities of potato glycoalkaloids against Trogoderma granarium (Coleoptera: Dermestidae). Journal of Stored Products Research., 47: 185-190.

9. Grainge, M. and Ahmed, S. (1988). Handbook of Plants with Pest-Control Properties. Wiley-Interscience.

10. Guilin, L., Wangxi, D. (1996). The community quantitative characters of insects on the stored TCM materials. Journal of Huazhong Agriculture University., 15: 338-345.

11. Hayes Jr., J. B., Laws Jr., E. R. (1991). Handbook of Pesticide Toxicology. Academic Press, San Diego, 1: 496.

12. Hidalgo, E., Moore, D., Patourel, L. E (1998). The effect of different formulations of Beauveria bassiana on Sitophilus zeamais in stored maize. Journal of Stored Products Research., 34: 171-179.

13. Hill, J. M., Schoonhoven, A. V. (1981). The use of vegetable oils in controlling insect infestations in stored grains and pulses. Recent Advances in Food Science and Technology., 1: 473-481.

14. Huang Ho, S. J., Wang, K. Y., Sim, G. C. L., Ee Z, Imiyabir K. F., Yap, K., Shaari, S., Hock, G. (2003). Meliternatin: a feeding deterrent and larvicidal polyoxygenated flavone from Melicope subunifoliolata. Phytochemistry., 62: 1121-1124.

15. Huang, Y.S, Ho, H., Lee, H.C, Yap, Y.L. (2002). Insecticidal properties of eugenol, isoeugenol and methyleugenol and their effects on nutrition of Sitophilus zeamais Motsch. (Coleoptera: Curculionidae) and Tribolium castaneum (Herbst) (Coleoptera: Tenebrionidae). Journal of stored Products Research., 38: 403-412.

16. Isman, M. B., Koul, O., Luczynski, A., Kaminskis, J. (1990). Insecticidal and antifeedant bioactivities of neem oils and their relationship to azadirachtin content. Journal of Agriculture and Food Chemistry., 38: 1406-1411.

17. Ivbijaro, M.F., Agbaje, M. (1986). Insecticidal activities of Piper guineense and Capsicum species in cowpea 
bruchid, Callosobruchus maculatus. Insect science and its Application., 7: 521-524.

18. Jacobson. M. (1990). Glossary of Plant-derived Insect Deterrents. CRC Press, Inc., Publication, New York, NY.

19. Khan, A. R., Selman, B. J. (1988). On the mortality of Tribolium castaneum adults treated sublethally as larvae with pirimiphos methyl, Nosema whitei and pirimiphos methyl-N. whitei doses. Entomophaga., 33: 377-380.

20. Khani, M., Awang, R. M., Omar, D., Rahmani, M. (2013). Toxicity, antifeedant, egg hatchability and adult emergence effect of Piper nigrum L. and Jatropha curcas $L$. extracts against rice moth, Corcyra cephalonica (Stainton). Journal of Medicinal Plants Research., 7: 1255-1262.

21. Konstantopoulou, L., Vassilopoulou, L., MauraganiTsipidov, P., Scouras, Z. G. (1992). Insecticidal effects of essential oils. A study of the effects of essential oils extracted fromeleven Greek aromatic plants on $D$. auraria. Experientia 48: 616-619.

22. Kumar, R., Kumar, A., Prasad, C. S., Dubey, N. K., Samant, R. (2008). Insecticidal activity Aegle marmelos (L.) Correa essential oil against four stored grain insect pests. Internet Journal of Food Safety., 10: 39-49.

23. Kumar, R., Srivastava, M., Dubey, N. K. (2007). Evaluation of Cymbopogon martini oil extract for control of postharvest insect deterioration in cereals and legumes. Journal of Food Protection., 70: 172-178.

24. Mahdi, S. M. R. (2008). Insecticidal effect of some spices on Callosobruchus maculatus (Fabricius) in black gram seeds. University Journal of Zoology Rajshahi University 27, 47-50.

25. Marsans, G. (1987). Manejo y ConservacioÂ n de Granos. Ed. Hemisferio Sur, Buenos Aires, 266.

26. Menn, J. J. (1996). Biopesticides: Has their time come? Journal of Environmental Science Health., 31: 383-389.

27. Nansen, C., Phillips, T. W. (2004). Attractancy and toxicity of an attracticide for Indian meal moth, Plodia interpunctella (Lepidoptera: Pyralidae). Journal of Economic Entomology., 97, 703-710.

28. Nawrot, J., Harmatha, J. (1994). Natural products as antifeedants against stored products insects. Postharvest News and Information., 5: 17-21.

29. Ofuya, T. I. (1992). Oviposition deterrence and ovicidal properties of some plant powders against Callosobruchus maculatus in stored cowpea seeds. Journal of Agricultural Science., 115: 343-345.

30. Okonkwo, E. U., Okoye, W. I. (1996). The efficacy of four seed powders and the essential oils as protectants of cowpea and maize grains against infestation by Callosobruchus maculatus and Sitophilus zeamais. Nigeria International Journal Pest Management., 42: 143-146.

31. Pinto Jr, A. R., Furiatti, R. S., Pereira, P. V. S., Lazzari, F. A. (1997). Avaliac ${ }^{\circ}$ ao de Insecticidas no Controle de Sitophilus oryzae (L.) (Coleoptera: Curculionidae), Rhyzopertha dominica (Fab) (Coleoptera: Bostrichidae) em Arroz Armazenado. Anais da Sociedade Entomologica do Brasil 26, 285-290.

32. Shukla, R., Singh, P., Prakash, B., Kumar, A., Mishra, P.K., Dubey, N.K., 2011. Efficacy of essential oils of Lippia alba (Mill.) N.E. Brown and Callistemon lanceolatus (Sm.) Sweet and their major constituents on mortality, oviposition and feeding behaviour of pulse beetle, Callosobruchus chinensis L. Journal of Science Food and Agriculture., 91: 2277-2283.

33. Singh, G., Upadhyay, R. K. (1993). Essential oils: a potent source of natural pesticides. Journal of Scientific and Industrial Research., 52: 676-683.

34. Subramanyam, B., Hagstrum, D. W. (1995). Resistance measurement and management. In: Subramanyam, B., Hagstrum, D.W. (Eds.). Integrated Management of Insects in Stored Products. Marcel Dekker, New York, 331-397.

35. Varma. J., Dubey, N.K. (2001). Efficacy of essential oils of Caesulia axillaris and Mentha arvensis against some storage pests causing biodeterioration of food commodities. International Journal of Food Microbiology., 68: 207-210.

36. White, N. D. G., Leesch, J. G. (1995). Chemical control. In: Subramanyam, B., Hagstrum, D.W. (Eds.), Integrated Management of Insects in Stored Products. Marcel Dekker, New York, 287-330. 